\title{
Sibirya Sahası Türk Destanlarında Kadının Yeri ve Bu Bağlamda Eski Türklerin Kadına Bakışı
}

\section{The Place of Woman in Siberian Realm Turkish Legends and the Perception of Ancient Turks in This Regard}

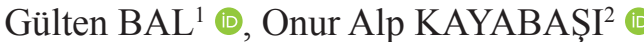

'Sorumlu yazar/Corresponding author: Gülten Bal (Doktora Öğrencisi),

Aksaray Üniversitesi, Sosyal Bilimler Enstitüsü, Aksaray, Türkiye

E-posta: gultenbal80@gmail.com

ORCID: 0000-0003-4552-2286

${ }^{2}$ Onur Alp Kayabaşı (Doç. Dr.), Aksaray Üniversitesi, Eğitim Fakültesi, Türkçe ve Sosyal Bilimler Eğitimi, Aksaray, Türkiye E-posta: onuralpkayabasi@hotmail.com ORCID: 0000-0002-4744-4798

Bassvuru/Submitted: 04.09 .2019

Revizyon Talebi/Revision Requested: 12.10.2019

Son Revizyon/Last Revision Received:

22.10.2019

Kabul/Accepted: 26.10 .2019

Online Yayın/Published Online: 13.11.2019

Atıf/Citation: Bal, Gulten ve Kayabasi, Onur Alp. "Sibirya Sahası Türk Destanlarında Kadının Yeri ve Bu Bağlamda Eski Türklerin Kadına Bakıșı."

Türkiyat Mecmuasi-Journal of Turkology 29, 2 (2019): 419-434.

https://doi.org/10.26650/iuturkiyat.646171
ÖZ

Günümüzde kadın, hâlen varlığını hissettirme ve kendini kanıtlama çabası içerisindedir. Ülkemizde ve dünyada yapılan sosyolojik araştırmalara bakıldığında kadının konumu itibariyle erkeğin çok gerisinde olduğu değerlendirilir. Ancak Türk tarihi, edebiyatı ve kültürü incelendiğinde Eski Türklerde kadının sosyal hayattaki yerinin günümüz kadınlarından çok daha yukarıda olduğu görülür. Eşinin yoldaşı, hayat arkadaşı, çocuklarının anası olan kadın doğurganlığı münasebetiyle hayatın kaynağı durumundaki saygın bir varlık olarak anılır.

Bu çalışmada Türklerin ortaya çıktığı ve ana yurdu olarak bilinen Asya kıtasında yer alan; günümüzde Rusya Federasyonu toprakları içerisinde kalan Ural Dağları'ndan Pasifik Okyanusu'na kadar olan alanı kapsayan Sibirya Sahası'nda yaşamış ve hâlen yaşamakta olan halklardan Yakut (Saha), Tuva, Hakas, Şor ve Altay Türklerinin destanlarındaki kadın kavramı destan metinlerinden verilen örnekler aracılığıyla incelenmiştir.

İncelenen destan metinlerinde kadının Eski Türklerdeki statüsünün erkekle eşit olduğu hatta daha üst konumda algılandığı, Türklerde cinsiyet ayrımı bulunmadığı ve kadının negatif ayrımcılığa maruz kalmadığı görülmektedir. Türk kadının bulunduğu konum ve statüsü itibariyle hayatın her alanında erkeğin yanında yer almasının, çağdaşları olan diğer dünya halklarıyla kıyaslandığında Eski Türk toplumlarının son derece gelişmiş bir kültür yapısına sahip oldukları sonucunu doğurmaktadır.

Anahtar kelimeler: Kadın, Sibirya Sahası, Destan, Eski Türkler, Mitoloji

\section{ABSTRACT}

Today, women are still struggling to feel their existence and prove themselves. According to the research conducted in our country and the World, it has been estimated that women are surpassed by men with regard to their status. Nevertheless, when Turkish history, literature and culture are analyzed, the place of women in social life in Old Turks was far above women today. Women, who were spouses, companions of their husbands, and mothers of their children, were seen as prestigious, as the source of life in reference to fertility. In this study, the concept of women in the legends of Yakut (Saha), Tuva, Hakas, Şor and Altay Turks, who used to live in the Siberian Realm, which ran from Ural Mountains to the Pacific Ocean in the modern Russian Federation, was located 
in the Asian content, where Turkish people emerged and knew their homeland, will be analyzed with the help of examples from the legend contexts.

In the epic texts examined, it is seen that the status of women in the Old Turks is equal to, or even higher than that of men. There is no gender discrimination in the Turks, and women are not exposed to negative discrimination. The fact that Turkish women stood by men in all spheres of life, in terms of their position and status leads us to the conclusion that Old Turkish societies had a highly developed cultural structure when compared to other world peoples who were their contemporaries.

Keywords: Woman, Siberian Realm, Epic, Old Turks, Mythology 


\section{Giriş}

Sibirya, Asya kıtasının kuzeyinde yer alan ve kıtanın yüzde kırkını oluşturan bölgenin ismi olup bu isim Ural dağlarının doğusundaki Tobol, İrtiş, İşim, Obi ırmaklarını içine alarak Altay dağlarına kadar uzanan bölge için kullanılmıştır. Rusların sömürgecilik politikasının devreye girmesiyle bölge XVI. yüzyılda istilâ edilmiştir. Bu süreçten sonra "Sibir" coğrafî terimi Rusya’nın Türkistan ve Kafkas sömürgelerinden başka Asya' daki bütün sömürgelerini tanımlayan bir terim hâline gelmiştir. ${ }^{1}$

Bölgede hâlen Rusya Federasyonu'na bağlı olarak yaşamakta olan Sibirya bölgesi Türk halkları dil, kültür ve inanç bakımından özgünlüklerini korumaya çalışmakta ve ana yurtlarından göç etmeyen Türk toplulukları olmaları sebebiyle dikkat çekmektedirler.

Türklerin tarih sahnesine çıktıkları zaman, net olarak bilinmemekle birlikte ilk ana vatanları Avrasya'nın kuzey bölgeleridir. Buralarda dimdik göğe yükselen gövdeleriyle kozalaklı çamların doldurduğu, alabildiğine uzanan sonsuz ve muazzam alanlar olarak Sibirya ormanları bulunur. ${ }^{2}$ İnsan gözü ile bakıldığında ulaşılmaz gibi görünen dağlar, her yeri çepeçevresaran sular, kış mevsiminin uzun geçtiği, aylarca karla kaplı ormanlar burada yaşayan insanları deyimi yerindeyse büyüler. İnsanoğlu bu muhteşem büyüklükteki doğa karşısında hayranlıkla karışık korku ve büyük bir saygı duyar. Soğuğun, yalnızlığın ve olağanüstü doğanın arkasında bilinmezlerin, büyük güçlerin zenginliğini hisseder. Böyle bir coğrafyada yaşamış olan ilk Türklerin gelenek ve inanç sistemlerini bu zenginliğin etkilediği muhakkaktır.

Bilinmeyen zamanlarda ortaya çıkan ve zamanla şekillenerek gelişen, dünyanın yaratılışı, insanların ve diğer canlıların var oluşları hakkında toplumun ortak inancını ve düşüncesini yansıtan söylencelere mit adı verilir. Fuzuli Bayat mit tanımını yaparken değerler dizisinde dünyayı algılama, şekillendirme, sembolleştirme yani hayatın ve olayların genelleştirilmiş modeli tanımını kullanır. ${ }^{3}$ Eliade ise mit tanımını şu şekilde yapar:

Mit kutsal bir öyküyü anlatır; en eski zamanda, "başlangıçtaki” masallara özgü zamanda olup bitmiş bir olayı anlatır. Bir başka deyişle mit, doğaüstü varlıkların başarıları sayesinde, ister eksiksiz olarak bütün gerçeklik, yani kozmos olsun, isterse onun yalnızca bir parçası (sözgelimi bir ada, bir bitki türü, bir insan davranış1, bir kurum) olsun, bir gerçekliğin nası1 yaşama geçtiğini dile getirir. Demek ki mit, her zaman bir “yaratılış”ın öyküsüdür. Bir şeyin nasıl yaratıldığını, nasıl var olmaya başladığını anlatır. Mit ancak gerçekten olup bitmiş, tam anlamıyla ortaya çıkmış olan şeyden söz eder. ${ }^{4}$

Altay-Sayan ve Sibirya Türklerinin günümüz sözlü ve yazılı edebiyatının en önemli kaynağı

1 Nadir Devlet, "Federe ve Muhtar Türk Cumhuriyetleri”, Türkler Ansiklopedisi, c. 20, (Ankara: Yeni Türkiye Yayinlar1, 2002), 23-82.

2 Jean Paul Roux, Türklerin Tarihi: Pasifik'ten Akdeniz'e 2000 Yıl, çev. Lale Arslan Özcan (İstanbul: Kabalc1 Yayınlar1, 2007), 50-52.

3 Fuzuli Bayat, Mitolojiye Giriş, (İstanbul: Ötüken Neşriyat, 2007), 11.

4 Mircea Eliade, Mitlerin Özellikleri, çev. Sema Rifat (İstanbul: Alfa Mitoloji, 2014), 17. 
mitlerdir. Buradan hareketle mitlerin kaybolmadığını zamanla fonksiyon değişikliğine maruz kaldığını söyleyebiliriz. Mitoloji sadece sözlü ve yazılı edebiyatın kaynağı olmakla kalmaz, diğer taraftan kültürün özünü oluşturur. Bu bağlamda mitolojiyi araştırmak kültürümüzün temelini araştırmak anlamına gelmektedir. ${ }^{5}$

Mitoloji kavramının aklailkgetirdiği olgu “destan”dır. Mitoloji ve destan aslındabirbirlerini tamamlayan iki unsurdur. Öyleyse diyebiliriz ki, mitolojik inanç sistemleri, insanların yaşantılarına sirayet etmiş ve sözlü halk edebiyatının bir örneği olan destanlar da mitlerden esinlenerek ortaya çıkmışlardır.

Sözlü edebiyatın örneklerinden biri olan destanlar, yazının bulunmasından önce insanların ilkel yaşam şartlarına sahip olduğu ve bilimin hayatlarına hükmetmediği çağlarda ıstıraplarını, sevinçlerini, büyükgöçlerini veya varlık-yoklukmücadeleleriniolağan dışı unsurlararacılığıyla beyan ettikleri anlatılardır. ${ }^{6}$ Destan metinlerinde karşılaşılan olağanüstülükler mitoloji ile anlam bulmaktadır. Mitolojik unsurları fazlasıyla barındıran destan metinleri dünya üzerinde yaşamış ve yaşamakta olan halkların millî karakterini tanımlayan en önemli eserlerdir. Mitik unsurları sıklıkla kullanan destanlar kültür tarihi incelemelerinde, incelenen toplumun ortak değerlerini yansıtması açısından ilk bakılması gereken kaynaklardır.

Türk destan geleneğinde, destanların tarihî bir dönemi birçok yönüyle anlattığını görürüz. Yaşananların milletler üzerinde bıraktığı etkiyi destan mantığı çerçevesinde işlerler. Olayların gerçekleşmesi, savaşlar, kahramanlıklar, günün koşulları gibi konular bütünlük gösterir. Kazak bilim adamı Şakir İbrayev'in ifadesiyle söyleyecek olursak, "Destanda tarihin görünüşünü araştırmak şarttır. Fakat bu tür araştırmalarda yer alan yanlışlıklardan birisi, destanın tarihle uyuşmayan özelliklerini geçiştirmek ya da bunları tarihten sapmak diye kabul etmektir. Bu, araştırmacının destan geleneğine yaptığı bir haksızlıktır."

Öyle ki tarihî olay destan içinde çekirdek unsur olarak kullanılmaktadır. Destan metinleri içerisinde kullanılan mübalağalı anlatımlar, zaman zaman hayal gücünün doruk noktalara çıkması gibi nedenlerle sadece destan metinleri incelenerek net bir sonuca ulaşmak mümkün değildir. Ancak bu metinlerden söz konusu halkların genel yaşayış biçimleri hakkında çok önemli bilgiler elde edilebilmektedir.

Millî destanların oluşabilmesi için o milletin başından kendilerini çok etkileyecek büyük olaylar geçmesi gerekmektedir. Türk destanları incelendiğinde eski çağlarda, büyük bir coğrafyada yaşamış olan Türk milletinin, açıklayamadığı doğa olayları, savaşlar, kuraklık, kıtlık ve bunun benzeri gelişmeler neticesinde anlatılan, kuşaktan kuşağa aktarılarak güçlenen bu destanları oluşturdukları görülmektedir.

Dolayısıyla toplumların kültürlerinin, inanç sistemlerinin, yaşam ve ölüme dair bütün

5 Bayat, Mitolojiye Giriş, 72.

6 Bilgehan Atsız Gökdağ ve Kemal Üçüncü, Başlangıcından Günümüze Türk Destanları, (Ankara: Akçağ Yayınlar1, 2013), 11.

7 Haz. Sadık Tural, Türk Dünyası Ortak Edebiyatı, Türk Dünyası Edebiyat Tarihi, (Ankara: Atatürk Kültür Merkezi Yayınları, 2001) 1:93. 
duygu ve düşüncelerinin yansıtıldığı destan metinlerinden yola çıkılarak o toplumun değer yargıları, yaşam tarzları, kutsalları veya tabuları gibi konular hakkında fikir edinmek mümkün görünmektedir.

\section{Yöntem}

Bu çalışmada Türklerin ortaya çıktığı ve ana yurdu olarak bilinen Asya kıtasında yer alan günümüzde Rusya Federasyonu toprakları içerisinde kalan, Ural Dağları'ndan Pasifik Okyanusu'na kadar olan alanı kapsayan Sibirya Sahası'nda yaşamış ve hâlen yaşamakta olan halklardan Yakut (Saha), Tuva, Hakas, Şor ve Altay Türklerinin destanlarındaki kadın kavramı destan metinlerinden verilen örnekler aracılığıyla incelenmiştir.

İnceleme yapılırken kadının, olay akışında yardımcı karakter veya kahramanın bizzat kendisi olarak yer aldığı bazı destan metinlerinden örnekler verilmiş, bu metinlerden yola çıkılarak Eski Türklerde kadının konumu ile ilgili değerlendirmeler yapılmıştır.

\section{Bulgular ve Tartışma}

Milletlerin kültür tarihleri incelendiğinde kadının toplumdaki yerinin, o milletin gelişmişlik düzeylerini belirlediği görülür. İnsanlık tarihinin başlangıcından bu yana kadın yaşamın her anında var olmasına rağmen dünya üzerindeki toplulukların büyük kısmında erkeğin gölgesinde kalmıştır.

Örnek verilecek olursa, İslâmiyet öncesi dönemde kız çocuğa sahip olmayı utanç kaynağ olarak gören bir anlayışın bulunduğu ya da batı medeniyetlerinde kadının birey olarak toplumda var olabilmesi için XX. yüzyılın başlarına kadar beklemesi gerektiği görülür.

Buna karşın Eski Türk tarihi incelendiğinde kadının erkekten ayrı tutulmadığı, sosyal hayatta her zaman var olduğu, hatta özel bir yerde konumlandırıldığı görülür.

Türk kültüründe kağanın eşi hatunların siyasî güçleri incelendiğinde de kadının yeri hakkında önemli bulgulara ulaşılmaktadır. Hatun unvanı özel bir törenle alınır ve devlet idaresinde büyük yetkileri bulunmaktadır. Eşleri savaştayken yerlerine hatunlar vekâlet ederken eşi vefat edince oğullarının küçük olması nedeniyle tahta geçen kadınlar olduğu gibi, elçileri ve başka ülke hükümdarlarını karşılama töreninde hazır bulunmaları ve hatunlara özel oluşturulan şehirler onların siyasi güçlerini göstermesi bakımından önemlidir.

Türk kadınının hukuki olarak da erkekle eşit haklara sahip olduğu görülür. Servetin kadın ve erkek arasında eşit dağıtılması ve kadının boşanma hakkının bulunması bu durumu kanitlamaktadır. $^{8}$

Türk kadının toplumsal hayattaki yerini Dr. Latife Kabaklı Çimen şöyle aktarır: "Türklerin tarih sahnesinde yer aldıkları en eski devirlerdeki Türk ailesinde kadın kocası ile aynı hak ve hukuka sahiptir. Türk ailesinin kuruluşunda karşılıklı saygı ve eşitlik prensibi hâkimdi.",9

8 İbrahim Tellioğlu, "İslam Öncesi Türk Toplumunda Kadının Konumu Üzerine” Atatürk Üniversitesi Türkiyat Araştırmaları Enstitüsü Dergisi (2016), 209-224.

9 Dr. Latife Kabaklı Çimen, Türk Töresinde Kadın ve Aile, (İstanbul: IQ Kültür Sanat Yayıncılık, 2008$), 119$. 
Türklerdekutsiyetatfedilen “AileveOcak”kavramlarının devamınısağlamada doğurganlığı sebebiyle önem atfedilen kadının, aynı zamanda kılıç kullanma, ata binme gibi günümüzde erkeğe özgü olduğu düşünülen eylemlerde en az onlar kadar ustalaşması, devlet yönetiminde her daim erkeğin yanında bulunması bu durumu kanıtlar niteliktedir.

Türk kültüründe ocak yaşanılan yer, ev, aile, boy anlamlarında kullanılmakta olup barınılan yerin ve ailenin kutsiyetine inanılırdı. Evde veya çadırda yanan ateş ise ailenin koruyucusu, bolluk ve bereketin simgesi olarak görülmekteydi.

Türk kültüründe ateş ve ocak canlı bir varlık olarak düşünülür. Örneğin Tuva Türklerinde her ocağın bir iyesi (sahibi) vardır. İnsanları koruduğuna inanılan bu iye özellikle çocukları ve hayvanları musibetlerden ve hastalıklardan korur. Böyle olunca da ateş, aile ocağının en önemli zenginliğidir. ${ }^{10}$ Sibirya Türkleri arasında karşılaşılan bu tür inanışlar ateş ve ocak iyesinin kutsal ve koruyucu bir varlık olarak düşünüldüğünü göstermektedir.

Ocağın ve soyun devamını sağlayan kadındır. Bu yüzdendir ki yeni evlenen kadın eve girerken eşiğe selam verir ve saçı (kansız kurban) yapar onu kutsar. Bundan başka evde bulunan ocağa ve ateşe sayg1 gösterisinde bulunur ve ona bakmakla, sürekli beslemekle görevlidir. Hakas Destanı Altın Taycı'da bu ritüel şöyle aktarılır:
Altın Arı̆̆, ayağa kalkıp
Ala kâseli içkisini sağ elinde tutarak,
Öncelikle ateşe serper,
İkincisini kapıya serper,
Üçüncüsünü duman deliğinden saçar.
Ak keçeyi atıp ateşin başına oturdu.

Eski Türklerde kadının hem ev içinde hem dışında konumu oldukça yüksektir. Bazen aile reisi olduğu görülürken evinin de direğidir. Erkeğinin yol arkadaşı, çocuklarının saygıdeğer annesidir. Siyasi olarak devlet yönetiminde bulunduğu gibi ekonomik ve sosyal hayatta ve hatta savaşlarda erkeğin yanında yer bulduğu görülür. ${ }^{12}$

Türk mitolojisinde kadına yaratılıştan önce rastlanır. Henüz dünya ve kâinat yokken, canlı adına herhangi bir şeyin olmadığ 1 zamanlarda Tanrı'ya yaratacağı dünyalar için ilham veren kişi Ak Ene diye adlandırılan kadın figürüdür:

"Bir Ak-Ana (Ak-Ene) var idi, yaşardı su içinde,

Ülgen'e şöyle dedi, göründü su yüzünde:

Yaratmak istiyorsan, sen de bir şeyler Ülgen,

Yaratıcı olarak, şu kutsal sözü öğren!

De ki hep, 'Yaptım oldu!' Başka bir şey söyleme!

10 Satı Kumartaşlıoğlu, “Türk Kültüründe Ateş ve Ocak İyeleri”, Karadeniz Araşttrmaları Dergisi 2014/43, 179.

11 Gülsüm Killi Yılmaz, Hakas Destanlarl 4 Altın Taycı. (Ankara: Türk Dil Kurumu Yayınları, 2013), 133.

12 Cimen, Türk Töresinde Kadın ve Aile, 119. 
Hele yaratır iken, 'Yaptım olmadı!' deme!, Ak-Ana bunu dedi, sonra kayboluverdi, Denize dalıp gitti, bilinmez n'oluverdi. Ülgen'in kulağından bu buyruk hiç çıkmadı, İnsana bu öğüdü iletmekten bıkmadı:

Dinleyin, ey insanlar! Var'1 yok demeyiniz! Varlığa yok deyip de, yok olup gitmeyiniz!" ${ }^{13}$

Ay-Atam isimli efsane de ilk insanların yaratılmasını ve bir kadın ve bir erkekten çoğaldıklarını anlatır. Ay-Atam ve Ay-va isimli bu ilk insanların isimlerinin ve hikâyelerinin Âdem ve Havva ile olan benzerliği dikkat çekmektedir. Prof. Dr. Bahaeddin Ögel Ay-Atam efsanesini şu şekilde aktarır:

Çok çok eski çağlarda çok yağmurlar yağmış; çamurlar sürüklenmiş. Sellerin önündeki çamurlar, bir yol bularak Kara-da adlı bir dağın içindeki bir mağaraya dolmuşlar. Mağaranın içindeki kayalar yarılmıs. Kaya yarıklarının bazıları bir insanı andırıyormuş. Sürüklenen çamurlar gelip bu insan kalıplarını doldurmuşlar.

Aradan çok zaman geçmiş. Yarıklardaki toprak, sular ile benzeşmiş ve hâllolmuş. Saratan burcuna gelince havalar çok 1sınmış. Kalıplardaki toprak sular ile pişmiş. Halka göre bu mağara tıpkı bir kadın gibi imiş. İçi de insanlara can veren bir "kadın karnı" gibi imiş.

Dokuz ay hiç durmadan bir rüzgâr esmiş. Su, ateş, toprak ve rüzgâr (yani dört unsur) insana can vermek için birleşmişler.

Ay-Atam adlı "ilk insan” böylece oluşmuş. Ay-Atam gökten inmiş yere konmuş. Bu yerin suyu tatl1, havası ise çok serinmiş. (Türklerin inanışlarına göre burası Isığ-göl olabilir.) Sonra yine yağmurlar ile seller başlamış. Mağara yeniden killer ve çamurlar ile dolmuş. Bu kez güneş gelip Sünbüle burcunda durmuş. Bu burç Saratan'dan daha aşağıda durmuş. Sünbüle burcundaki güneşin sıcaklığı ile çamurlar, sular ile pişmiş.

Bir hatun kişi çıkmış. Adına da "Ay-va" demişler. (Kadının adının manası anlaşılmıyor. Ay bir güzellik sembolüdür.) Ay-Atam ile Ay-va Hatun birleşip evlenmişler.

40 çocukları olmuş. Bunların yarısı erkek; diğer yarısı da kız imiş. Onlar da evlenip soyları çoğalmış. Ölümlü kişiler olanAy-AtamileAy-vaHatun ölüyorlar. Çocukları, anne ve babalarını türedikleri mağaraya gömüyorlar. Mağaranın kapısını da altın kapılar ile kapıyorlar. ${ }^{14}$

Görüldüğü üzere Türkler, diğer semavi dinlerdeki inanışlar gibi yaratılan ilk insanların bir kadın ve erkekten oluşan bir çift olduğuna ve neslimizin bunlardan türediğine inanıyorlardı. Bu durum bize Türk din ve mitolojisinin yaratılışı açıklarken tek Tanrının izinden gittiğini göstermektedir.

Türk kültürünü inceleyen araştırmacıların Türklerin inançları hakkında değişik savları bulunmaktadır. Ancak Türk mitolojisi incelendiğinde tek Tanrı inancı ile karşılaşılmaktadır. Türklerin geleneksel dininin tek Tanrılı mı yoksa çok Tanrılı mı olduğu konusunda yaşanan

13 Bahaeddin Ögel, Türk Mitolojisi I, (Ankara: Türk Tarih Kurumu Yayınları, 2010), 115.

14 Bahaeddin Ögel, Türk Mitolojisi II, (Ankara: Türk Tarih Kurumu Yayınları, 2010), 201-202. 
bu ikilemin ve görüş farklılıklarının ilk sebebi, Türk mitolojisi ile ilgili araştırmaların büyük çoğunluğunun batılı bilim adamları tarafından yapılmış olması, söz konusu araştırmacıların Türk kültürüne yabancı olmaları nedeniyle elde ettikleri bulguları yanlış ya da eksik yorumlamaları olarak düşünülmektedir.

Türklerin kut ve iye inançları Türk kültürünü ve inanç sistemini bilmeyen biraraştırmacı için nesnelere veya birden fazla Tanrıya tapma şeklinde algılanmıştır. Varlık sebebini arayan, yaşamını sürdürebilmesine imkân sağlayan her türlü canlı ya da cansız maddeyi kutsal kabul eden arkaik dönem insanının önem atfetmiş olduğu kutsal varlık ve nesneleri birer ilah gibi değil de kutu olan, ruhu olan varlıklar olarak algıladığı söylenebilir.

Yani diğer din ve mitolojilerde görüldüğü gibi (Yunan, Sümer, Hitit, Misır vb.) Türklerde Tanrıça kavramı bulunmamaktadır. Türk mitolojisinde yer alan doğaüstü güçler Mitolojik Ana kavramıyla açıklanabilir. Türkler için yaşadıkları coğrafya yani vatanları her zaman kutsal kabul edilmiştir. Tanrının kendilerine bahşettiği ve üzerinde hüküm sürdükleri topraklar "ana" kimliğiyle özdeşleştirilmiş, inançlar toprağın vericiliği üzerine şekillenmiştir.

Türk mitolojisinin en eski katmanında önce başlangıcı sağlayan yani doğumu simgeleyen ve sonra ölümle ikisini birleştiren Mitolojik Ana ya da daha somutlaşmış bir kavram olan Yer Ana varlığg 1 görülür.

Gerçekle hayali, maddi olanla manevi olanı kesin olarak ayıramayan arkaik dönem insanı, sürekli doğan, üreten, yaşlanan tabiatı canlı bir vücut olarak algılamıştır. Böylece gelişen tabiat kültü bağımsız bir varlık olarak algılanan YerAna kültünün oluşmasını sağlamıştır. ${ }^{15}$ Yere "ana" olarak hitap edilmesi ve kadınla ilişkilendirilmesi bir kadın, bir anne gibi sürekli vericiliği ve bağrından insanoğluna türlü nimetler sunması nedenlerine bağlanabilir.

Türk kültür tarihine bakıldığgnda mağaraların özel ve önemli bir yere sahip olduğu görülür. Türk mitolojisinde mağara önceleri Mitolojik Ana kültü daha sonra Umay kültü ile bağlantılı olarak gelişmiştir. Zaten dişil bir konumda olan YerAna ve onun rahmi olan mağara doğurganlık işlevini tek başına yürüttüğü hâlde, sonradan bu fonksiyon Umay Ana'ya devredilmiştir. ${ }^{16}$

Necati Gültepe bu durumu bütün dişil varlıkların Mitolojik Ana'nın türevleri olarak değerlendirmeye alındığını söyleyerek açıklar. ${ }^{17}$

Türk mitolojisinde kadın ile ilgili iki figür daha dikkat çekmektedir. Bunlardan ilki yukarıda bahsi geçen Umay diğeri de destan metinlerinde bulunan kadın kahraman tipidir. Umay'ın çocuklar ve annelerini korumakla görevli bir iye olduğu inancı mevcuttur. Kadınların hamilelik dönemlerinden başlayarak doğumda ve doğum sonrasında çocuk büyüyünceye kadar kötülüklerden koruduğuna inanılır. Çocukların, kadınların hayatında önemli bir yer tutan Umay üremenin yardımcısıdır. Anne ve bebeği kötülüklerden korur ve genel olarak dişil tasvir edilir.

Tonyukuk ve Kültigin yazıtlarında dünyanın yaratılışı esnasında bahsedilen Umay, Altay Türklerince May-Ene/Payana/Bay-Ene, Ymay Ene, Ayılıt adlarıyla da bilinir. Tonyukuk

15 Fuzuli Bayat, Türk Mitolojik Sistemi 2. (İstanbul: Ötüken Neşriyat, 2012), 52.

16 Bayat, Türk Mitolojik Sistemi 2, 13.

17 Necati Gültepe, Türk Kadın Tarihine Giriş, (İstanbul: Ötüken Neşriyat, 2008), 104-105. 
Yazıtında ikinci taş batı yüzü üçüncü satırda Umay İlâhe olarak geçer. ${ }^{18}$ Kültigin Yazıtında (doğu yüzü, otuz birinci satırda) ise anne figürü Hatun kişi Umay’a benzetilmektedir. ${ }^{19}$ Ak-sarı saçlı, ak-sarı simalı, ak giyimli olarak tasavvur edilir. Hamilelik ve sonrasında anneye yardım eder, bebek rahimdeyken onun kut'unu korur. Anne rahmine girerek çocuğun ölmesine veya düşmesine sebep olabilecek kötü ruhlardan korur, doğum esnasında doğumun gerçekleşmesini zorlaştıran, çocuğu kendine çeken kötü ruhlarla mücadele ederek doğumu kolaylaştırır ve bebeğin dünyaya gelmesine, göbek bağının kolay kesilmesine yardım eder. ${ }^{20}$

Fuzuli Bayat Türk Mitolojik Sistemi adlı çalışmasında Umay hakkında şu bilgileri verir:

Türk Mitolojik sisteminde Umay kültünün çok eski çağlarda Mitolojik Ana kompleksinden koptuğu (en azından 7. yüzyıl Göktürk anıt yazıtlarında Yer-Su ve Umay, ayrıca birerhami ruh gibi anılmıştır.) bilinmektedir. Bağımsız koruyucu ruh gibi şekillenen kutsal dişi-Umay/ May Ene (Yakutlarda karşılığı Ayısıt), Gök Tanrı dinî mitolojik sistemine alınmış ve ruhların hiyerarşik dizilişinde baş yerlerden birine konulmuştur. Türk Mitolojisinin bütün sahalarında etkili olan Şamanlık, Umay'ı da iki kutba ayırmıştır:

1. Etnografik literatürde çocukların, annelerin ve aile ocağının koruyucusu olan Umay. Bu Umay, Orhun-Yenisey abidelerinde Gök-Tanrı ile birlikte Türk milletinin ve Türk Devletinin koruyucusu gibi işlevselleşmiştir.

2. Çocukları öldüren Kara Umay ki buna bazı Altay kavimlerinde Karay May da denilir.

Fuzuli Bayat'ın dikkat çektiği Kara Umay aslında Umay'ın zamanla kötülük eden, zarar veren bir karaktere bürünmüş hâlinden başka bir şey değildir. ${ }^{22}$ Umay'ın "ateş ruhu” olarak da görülmesi nedeniyle doğum sonrası loğusa annede veya bebekte oluşan rahatsızlıklar Umay’a bağlanıyordu. Albastı veya Al Karısı gibi isimlerle anılan bu ruhun vereceği zararlardan korunmak için günümüzde de hâlen devam eden loğusa anne ve bebeğini 40 gün boyunca yalnız bırakmamak, yataklarının başlarına kırmızı yazma asmak, yastıklarının altına demir makas, bıçak gibi aletler koymak gibi uygulamalarla korunma sağlamaya çalışılmaktadır.

Umay kültünün Türk kültür tarihindeki yerinin kadının önemine bağlanması mümkündür. Öyle ki doğurganlık sembolü ve kadın ile çocuğun koruyucu ruhu olduğuna inanılan Umay’ın dişil karakteri ve ona duyulan saygı ile karışık korku, kendisine adaklar adanmasına, saçı yapılmasına, dualar edilmesine sebep olmuştur. Hatta yeryüzüne ilk gönderilen ve "hayat ağacı" olarak tasvir edilen kayın ağacı ile birlikte Umay da gelmiştir.

Kayın ağacı Türk mitolojisinde özellikle önemli bir yere sahiptir. Eski kaynaklarda kadın olarak geçtiği görülür. Örneğin Divân'ü Lûgati’t-Türk’te kadın şeklinde geçmesi dikkat çeker. Tuva ve Şorlarda kadın şeklinde kullanımı değişmeden kalmıştır. Türkçenin ilk zamanlarından

18 Muharrem Ergin, Orhun Abideleri, (İstanbul: Boğaziçi Yayınları, 2018), 109.

19 Ergin, Orhun Abideleri, 53.

20 Haz. Hayati Beşirli, Türk Kültürü El Kitabı, (Ankara: Grafiker Yayınları, 2015), 284.

21 Bayat, Türk Mitolojik Sistemi 2, 33.

22 Yaşar Çoruhlu, Türk Mitolojisinin Anahatları (İstanbul: Kabalcı Yayıncılık, 2011), 47. 
kalan bu kelimenin varlığı, Türklerin ana yurdunda bu ağacın bulunduğunu kanıtlar. ${ }^{23}$ İlk insan Er Sogotoh ve eşi yeryüzüne kayın ağacının bulunduğu yönden inerler. ${ }^{24}$ Umay da kadın ve çocukları korumak üzere Tanrı'nın emri ile yeryüzüne inerken yanında iki kayın ağacı getirmiştir. Yeryüzüneilk gönderilen ağacın isminin kadın figürü ile ilişkilendirilmesi de kadının orta dünyada başlayan hayatın ana kaynaklarından biri olarak görülmesi sebebiyle önemlidir.

Türk destanlarında kadına karşı duyulan sarsılmaz güven, sevgi, saygı ve bağlılık çokça dile getirilmiştir. Kadim zamanların Türk topluluklarında kadının erkeğin eksiği olarak değil de eşiti, hayat arkadaşı, başı sııışınca sırtını dayadığı yoldaşı olarak algılandığı görülür.

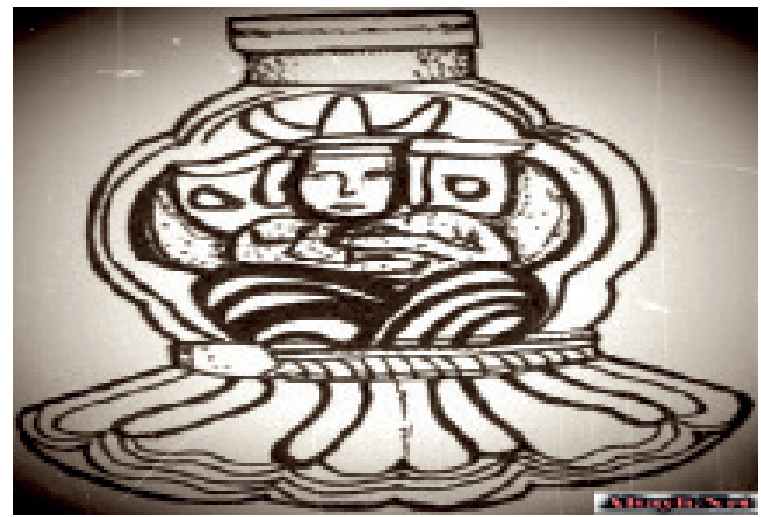

Şekil 1. Umay Ana Tasviri

(http://www.altayli.net/turk-takilarinda-umay-inancinin-izleri-ve-avrasya kokleri.html/3)

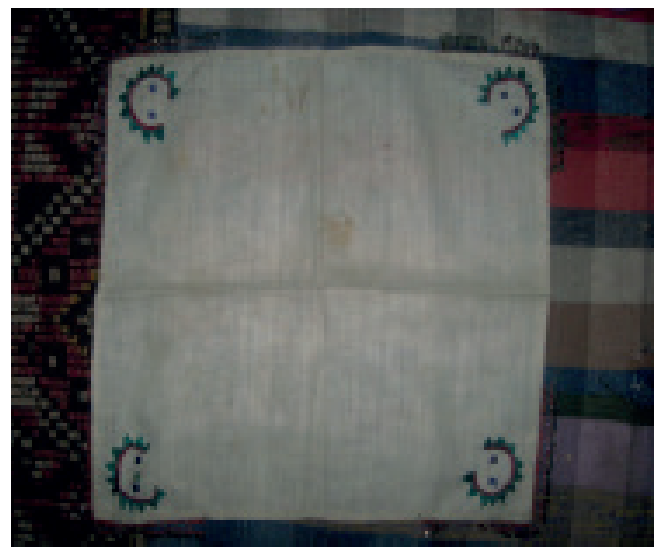

Şekil 2. Antropomorfik ișlemeli mendil (Kayabașı, O.A.(2016) Taşeli Yöresi Tahtacılarının Geçiş Dönemlerinde Mitolojik Unsurlar, Türk Kültürü ve Hacı Bektaş Velî Araştırma Dergisi, 78, 139)

23 Hasan Eren, “Türklerin Ana Yurdu Sorunu”, Türk Dili 2001-II, 600-685.

24 Metin Ergun, Yakut Destan Geleneği ve Er Sogotoh (Ankara: Türk Dil Kurumu Yayınları, 2013), 799. 
Türk Kültürüne 1şık tutan en önemli belgelerden olan Dede Korkut Hikâyeleri’nde de kadın yüceltilir:

Beri gel başımın bahtı evimin tahtı

Evden çıkıp yürüyünce selvi boylum

Topuğunda sarmaşınca kara saçlım

Kurulu yaya benzer çatma kaşlım,

Çifte badem sığmayan dar ağızlım

Güz almasına benzer al yanaklım

Kadınım, direğim, kuvvetim. ${ }^{25}$

Uygurca Oğuz Destanında Oğuz'un oğullarından Gün, Ay, ve Yıldız'ın annesinin ay ve güneşten indiği anlatılır:

Oğuz Kağan bir yerde, Tanrıya yalvarırken:

Karanlık bastı birden, bir ışık düştü gökten!

Öyle bir 1şık indi, parlak aydan, güneşten!

Oğuz Kağan yürüdü yakınına 1şığın,

Oturduğunu gördü, ortasında bir kızın!

Bir ben vardı başında, ateş gibi 1şı̆̆ı,

Çok güzel bir kızdı bu, sanki Kutup Yıldızı!

Öyle güzel bir kız ki, gülse gök güle durur!

Kız ağlamak istese, gök de ağlaya durur!

Oğuz kızı görünce, aklı gitti beyninden,

Kıza vuruldu birden, sevdi kızı gönlünden,

Kızla gerdeğe girdi, aldı dilediğinden.

Gebe kalmış idi kız, gün geceler dolunca,

Gözleri aydın oldu, üç oğlancuk doğunca.

Birinci oğlancuğa, Gün adını koydular.

İkinci oğlanaysa, Ay adını buldular,

Yıldız olsun üçüncü diye memnun oldular! ${ }^{26}$

Olonholardaki ${ }^{27}$ kadın kahraman tipi ailenin temelidir. Anneliği ve ev hanımlığıyla öne çıkan kadın kahramanlar, bahadırların huzurlu bir hayat sürebilmelerinin ilk koşuludur ve kavuşmaları için bazen büyük mücadeleler vermeleri gerekir. Yakutlara göre onların eşyaları, hep en güzel ve en değerlidir. Kadın destanlarda her zaman iç ve dış güzelliğin sembolü olarak gösterilir. ${ }^{28}$ Güzelliklerinden övgüyle bahsedilir.

Sibirya yöresi Türk destanlarından Altın Arığ ve Altın Çüs destanlarının birer örnek

25 Yunus Zeyrek, Dede Korkut Kitabı (İstanbul: Ötüken Neşriyat, 2013), 36.

26 Ögel, Türk Mitolojisi I, 117.

27 Kahramanlık destanı

28 İnnokentiy Vasilyeviç Puhov, Yakut Kahramanlık Destanı Olonho; Genel Tipler, çev. Metin Ergun (Konya: Kömen Yayınları, 2015), 131. 
olarak verilebileceği "kadın kahraman” tiplerinin, İslâm öncesi Türk destanlarında sıklıkla yer bulduğu görülür. Bazı destanlarda ise merkezî roller yerine güçlü, olağanüstü özelliklere sahip ve şaman karakterli kadınlara da rastlanmaktadır. Altay destanlarından Maaday Kara' da bulunan Altay sahibesi yaşı kadın motifi, kahramanın ülkesinin Kara-Kula Kağan tarafından ele geçirilip halkını esir etmesinin ardından, yaşadığı dağdan aşağıya iner ve Maaday Kara'nın düşman eline geçmesin diye dağ başına terk ettiği oğlunu bulur. Çocuğu kurtarır, besler, anne ve babasının düştüğü durumu, kim olduklarını ona açıklar. ${ }^{29}$

Destanlarda bazen kadın kahramanlar da tıpk1 erkek kahramanlar gibi, bir anne-babadan değil de doğaüstü yollarla dünyaya gelirler. Örneğin Hakas Destanı Altın Arığ’da, Altay dağlarının koruyucusu olarak tanımlanan Altın Arığ dağın içinde anne-babası olmadan doğar, yani bedeni zaten oradadır ve ruh verilmesini beklemektedir. Ruhu kendisine verilince vatanı ve halkı için mücadele eden bir kahraman olur. ${ }^{30}$

Sibirya Sahası Türk Destanlarında kadın ile erkeğin kapışmasına sıklıkla rastlanmaktadır. Bu dövüş tıpkı iki erkek kahramanın kapışması gibidir ve aynı olağanüstü etkiyi vermektedir. Kadın ile erkek yine uzun süren dövüşler yapar, bu sırada dağlar, ağaçlar yıkılır, dünyayı duman kaplar, göz gözü görmez.

Altay Destanı Üç Kulaktu Ay Kara At destanında kadın kahramanın Alp kıyafeti giyerek savaşa girmesi şöyle anlatılır:

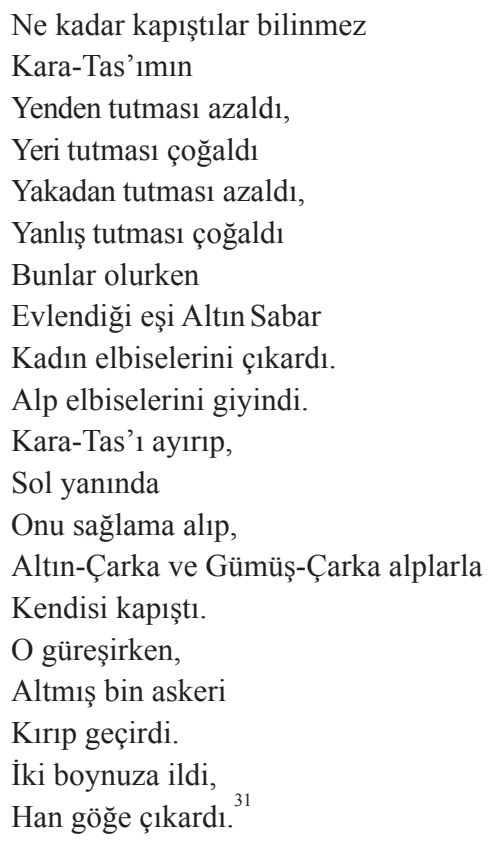

29 Emine Gürsoy Naskali, Altay Destanı Maaday - Kara (İstanbul: Yapı Kredi Yayınları, 2015), 80-100.

30 Fatma Özkan, Altın Arı̆̆ Destan. Ankara: Bilig Yayınları, 1997.

31 İbrahim Dilek, Altay Destanları 3 (Ankara: Türk Dil Kurumu Yayınları, 2007), 413. 
Hakas Destanı Kara Kuzgun'da bir örneği görüldüğü üzere, kadınlar bazen evlenmek istemedikleri talipleriyle büyük mücadeleye girişirler:

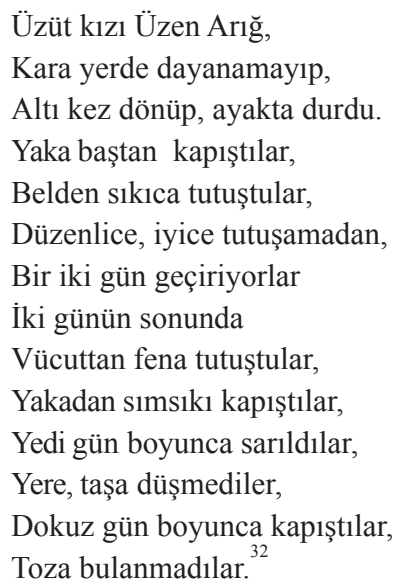

Türk kadın tarihi incelenirken dünya tarihinde sıklıkla ismine rastlanan ve Amazonlar olarak adlandırılan savaşçı kadınlara da kısaca değinmek gerekir. Necati Gültepe, Türk Kadın Tarihine Giriş isimli kitabında Amerikalı Arkeolog-Etnograf Prof. Dr. Jeannine Davis Kimball'ın Amazonların Turanî (Türk) olduklarını nasıl ispatladığını anlatır. Amazon kadınlarının mezarlarından alınan bulgularla büyük bir yolculuğa başlayan araştırmacı, Baykal gölünün güneyindeOrhonnehrikenarına kurulmuş birobadaki MeryemgülisimlibirTürkkızındanaldığı DNA örneği ile elinde bulunan 2.500 yıl önce yaşamış savaşçı kadına ait DNA örneklerinin karşılaştırmasını yapar ve elde ettiği sonuç şok edicidir: iki DNA \%99,9 oranında örtüşmektedir. Bu çalışma ile efsanevîAmazonların Türk soyundan oldukları bilimsel olarak kanıtlanmıştır. ${ }^{33}$

Türk kadınlarının savaşçı özellikleri yukarıda verilen örneklerden de anlaşılacağı üzere destanlarda sıklıkla işlenen konulardan biridir. Türk kültür araştırmalarında kadının erkekler gibi savaşlara ve mücadelelere katılması ile ilgili günümüze aktarılan bilgiler Dr. Jeannine Davis Kimball'ın araştırmasıyla somutlaşmıştır.

\section{Sonuç}

Türk kültüründe yaratılıştan itibaren yeri bulunan kadın, doğurganlığı nedeniyle toprağın insanoğluna verdiği nimetler ile ilişkilendirilmiş ve buna mukabil "yer ana" kavramının oluşmasında etkili olmuştur. Yine dünyanın yaratılmasından itibaren adı anılan "Umay" inancı ile bağlantılı olarak bu dişil varlık kadının ve çocukların koruyucusu olarak tasavvur edilir.

Kadının eski Türk sosyal hayatında en az erkek kadar önemli bir yeri bulunduğu ve yaşamın

32 Ali Ilgın, Hakas Destanları II Kara Kuzgun (Ankara: Türk Dil Kurumu Yayınları, 2008), 145.

33 Gültepe, Necati. Türk Kadın Tarihine Giriş. İstanbul: Ötüken Neşriyat, 2008. 
her yerinde izi olduğu görülmektedir. Kadının "ana" ve "hayat arkadaşı" olmasının yanı sıra fiziksel gücü ve aklı ile de erkeğin yanında yer bulduğu eski Türklerin devlet anlayışında "hatun" her zaman kağanın yanında yer almakta ve devlet yönetiminde söz sahibi bir konumda bulunmaktaydı. Türk kadını hukukî olarak erkekle eşit haklara sahip olduğu gibi aile birliğinin devamını sağlayan en önemli unsur olarak da algılanmaktaydı. Ocağın yanmasından, ocaktaki ateşe saygı gösterme ritüellerinden sorumlu olması bu durumu kanıtlamaktadır.

Hayat mücadelesinde erkekten geri durmayan Türk kadını savaşlarda da yer almaktan kaçınmaz, bir erkek gibi kıyasıya mücadelelere girer. Destan metinlerinde geçen bu ifadelerin doğruluğu savaşçı özellikleriyle bilinen Amazon kadınlarının DNA’sının bir Türk kızı ile uyumlu çıkması sonucu kanıtlanmıştır.

Sibirya Sahası destan metinleri incelendiğinde ve Türk kültüründe kadının yeri ile ilgili çalışmalara bakıldığında, Türklerde cinsiyet ayrımı bulunmadığg 1 ve kadının negatif ayrımcılığa maruz kalmadığg görülmektedir. Türk kadının bulunduğu konum ve statüsü itibariyle erkeğin yanında yer alması, çağdaşları olan diğer dünya halklarıyla kıyaslandığında eski Türk toplumlarının son derece gelişmiş bir kültür yapısına sahip olduklarını göstermektedir.

Binlerce yıl önce yaşamış olan atalarımızın hayatın kaynağı olarak gördüğü ve kutsiyet atfettiği kadının günümüzde karşılaştığı sorunların sebebinin, Türklerin öz kültürüne tam anlamıyla sahip çıkamayarak yabancı toplumların etkisi ile de güçlenen kültür yozlaşması olduğu düşünülmektedir.

\section{Kaynaklar}

Bayat, Fuzuli. Mitolojiye Giriş. İstanbul: Ötüken Neşriyat, 2007.

Bayat, Fuzuli. Türk Mitolojik Sistemi 2. İstanbul: Ötüken Neşriyat, 2012.

Çimen, Dr. Latife Kabaklı. Türk Töresinde Kadın ve Aile. İstanbul: IQ Kültür Sanat Yayınc1lık, 2008. Çoruhlu, Yaşar. Türk Mitolojisinin Anahatları. İstanbul: Kabalcı Yayınc1lı, 2011.

Devlet, Nadir. “Federe ve Muhtar Türk Cumhuriyetleri”. Türkler Ansiklopedisi. 20:23-82 Ankara: Yeni Türkiye Yayınları, 2002.

Dilek, İbrahim. Altay Destanları 3 . Ankara: Türk Dil Kurumu Yayınları, 2007. Eliade, Mircea. Mitlerin Özellikleri. İstanbul: Alfa Mitoloji, 2014.

Eren, Hasan. "Türklerin Ana Yurdu Sorunu” Türk Dili (2001-II), 600-685. Ergin, Muharrem. Orhun Abideleri. İstanbul: Boğaziçi Yayınları, 2018.

Ergun, Metin. Yakut Destan Geleneği ve Er Sogotoh. Ankara: Türk Dil Kurumu Yayınları, 2013.

Gökdağ, Bilgehan Atsız, ve Kemal Üçüncü. Başlangıcından Günümüze Türk Destanları. Ankara: Akçağ Yayınları, 2013.

Gültepe, Necati. Türk Kadın Tarihine Giriş. İstanbul: Ötüken Neşriyat, 2008.

Ilgın, Ali. Hakas Destanları II Kara Kuzgun . Ankara: Türk Dil Kurumu Yayınları, 2008.

Kayabaşı, Onur Alp. “Taşeli Yöresi Tahtacılarının Geçiş Dönemlerinde Mitolojik Unsurlar.” Türk Kültürü ve Hacı Bektaş Velî Araştırma Dergisi (2016) 78-139. 
Kumartaşlığlu, Satı. “Türk KültüründeAteş ve Ocak İyeleri”, Karadeniz Araştırmaları Dergisi (2014/43), 179. Naskali, Emine Gürsoy. Altay Destanı Maaday - Kara. İstanbul: Yapı Kredi Yayınları, 2015.

Ögel, Bahaeddin. Türk Mitolojisi I. Ankara: Türk Tarih Kurumu Yayınları, 2010. Ögel, Bahaeddin. Türk Mitolojisi II. Ankara: Türk Tarih Kurumu Yayınları, 2010. Özkan, Fatma. Altın Arı̆̆ Destanı. Ankara: Bilig Yayınları, 1997.

Puhov, İnnokentiy Vasilyeviç. Yakut Kahramanlık Destanı Olonho; Genel Tipler. Çeviren Metin Ergun. Konya: Kömen Yayınları, 2015.

Roux, Jean Paul. Türklerin Tarihi: Pasifik'ten Akdeniz'e 2000 Yll. Çeviren Lale Arslan Özcan. İstanbul: Kabalc1 Yayınları, 2007.

Tellioğlu, İbrahim. "İslam Öncesi Türk Toplumunda Kadının Konumu Üzerine.” Atatürk Üniversitesi Türkiyat Araştırmaları Enstitüsü Dergisi (2016): 209-224.

Türk Dünyası Ortak Edebiyatı, Türk Dünyası Edebiyat Tarihi. 1. cilt. Hazırlayan: Sadık Tural. Ankara: Atatürk Kültür Merkezi Yayınları, 2001.

Türk Kültürü El Kitabı. Hazırlayan: Hayati Beşirli. Ankara: Grafiker Yayınları, 2015.

Umay Ana Tasviri. “Türk Takılarında Umay İnancının İzleri ve Avrasya Kökleri” Erişim: 02 Eylül 2019. https://www.altayli.net/turk-takilarinda-umay-inancinin-izleri-ve-avrasya-kokleri.html.

Yılmaz, Gülsüm Killi. Hakas Destanları 4 Altın Taycı. Ankara: Türk Dil Kurumu Yayınları, 2013. Zeyrek, Yunus. Dede Korkut Kitabı. İstanbul: Ötüken Neşriyat, 2013. 
